Global Constitutionalism (2021), 10:1, 75-90 @ The Author(s), 2021. Published by Cambridge University Press. This is an Open Access article, distributed under the terms of the Creative Commons AttributionNonCommercial-NoDerivatives licence (http://creativecommons.org/licenses/by-nc-nd/4.0/), which permits non-commercial re-use, distribution, and reproduction in any medium, provided the original work is unaltered and is properly cited. The written permission of Cambridge University Press must be obtained for commerical re-use or in order to create a derivative work.

doi:10.1017/S2045381719000169

\title{
Judicial authority, legitimacy and the (international) rule of law as essentially contested and interpretive concepts: Introduction to the special issue
}

\author{
K N U T T R A I S B A C H iD \\ University of Barcelona, Diagonal 684 and University Ramon Llull, ESADE, Av. Pedralbes 60-62, \\ 08034 Barcelona, Spain \\ Email: traisbach@ub.edu
}

\begin{abstract}
Beyond setting the stage, the Introduction makes three claims about the conceptual triangle of the rule of law, judicial authority and legitimacy. The first is that all three are essentially contested and interpretive concepts in the sense of Walter B. Gallie and Ronald Dworkin. In their expositions, the contested and interpretative nature of such concepts is nothing to be 'solved', rather the formulation of different conceptions and contestation about them are central functions of such concepts. The interpretive and essentially contested nature points us to the relevant 'actors' and to conflicts and trade-offs between contested competencies. Thus the second point is that arguments about the rule of law and judicial legitimacy are often a means of questioning or securing the authority of a particular actor or institution in relation to other actors and institutions. The final point is that transposing concepts from the domestic to the supranational is a constructive endeavour because it entails creating new conceptions and substituting old ones as well as legitimising new authorities and delegitimising old ones. Thus, this special issue also cautions against discourses that ultimately are more about legitimation than about legitimacy and more about new ways of ruling than the rule of law.
\end{abstract}

Keywords: essentially contested and interpretive concept; conceptions; judicial authority; legitimacy; rule of law

\section{Ruling in the name of law}

The legitimacy of judicial authority and the (international) rule of law are the themes of this special issue. They relate to well-known questions in jurisprudence. Is the judicial settlement of disputes a requirement of the rule of law? May a supreme court review legislation according to constitutional standards that has been enacted by parliament according to constitutional procedures? Which rules, standards and principles 
may judges use to interpret the law and decide (hard) cases? May judges make law and thus take the law into their own hands?

Generations of jurists have struggled with these questions. Albert Venn Dicey, Oliver Wendell Holmes Jr., Karl Llewellyn, Herbert L. A. Hart, Thomas Henry Bingham, Ronald Dworkin, Joseph Raz, Lon Fuller and other eminent scholars - including many of the authors in this special issue have argued about the nature of law, the rule of law, the adequate role of judges and legitimate authority. These debates have their equivalent also beyond the domestic legal system in regional and supranational contexts (and of course also beyond the Anglo-American academic world).

The supranational judiciary has long been a central focal point of analysis in international legal and political scholarship. At the turn of the twentieth century, the focus lay on the desirability of supranational arbitration and the peaceful resolution of inter-state conflicts. Observers regarded the establishment of the first permanent international arbitration tribunal and other permanent international courts as an advancement of the rule of law in international affairs. It was proof for the validity and effectiveness of the international legal order in a world of sovereign states. ${ }^{1}$ Co-operation in international and regional organisations and through treaty regimes, preferably supervised by independent judicial or quasijudicial bodies, was a further step in this direction.

This paradigm has left its mark. Over the last three decades, the number of regional and international courts and tribunals has multiplied. ${ }^{2}$ It seems as if judicial oversight has become an epitome of the international rule of law. The more recent discussion about international courts and tribunals has thus focused again on the 'desirability' of supranational adjudication and on particular developments associated with activities of international judicial bodies. These include the role of courts for the regional co-operation and integration in Europe, the fragmentation/unity of the international legal order, transitional justice, transnational judicial governance networks and the interplay between national and supranational courts. ${ }^{3}$

1 RF Clarke, 'A Permanent Tribunal of International Arbitration: Its Necessity and Value' (1907) 1 American Journal of International Law 342; JB Scott, 'The Proposed Court of Arbitral Justice' (1908) 2 American Journal of International Law 772; H Lauterpacht, The Function of Law in the International Community (Oxford University Press, Oxford, 1933) 29-31.

${ }^{2}$ KJ Alter, The New Terrain of International Law: Courts, Politics, Rights (Princeton University Press, Princeton, NJ and Oxford, 2014).

${ }^{3} \mathrm{JHH}$ Weiler, 'The Least Dangerous Branch: A Retrospective and Prospective of the European Court of Justice in the Arena of Political Integration' in JHH Weiller (ed), The Constitution of Europe (Cambridge University Press, Cambridge, 1999) 188; A Stone Sweet, Governing with Judges: Constitutional Politics in Europe (Oxford University Press, Oxford, 
It's fair to say that the interest in the rule of law and in legitimacy in the international setting has increased while the long-discussed topic of the effectiveness of international law is hardly discussed anymore, at least not in absolute terms. The discussion has moved from whether international law matters to how it matters. Yet I would suggest that the ongoing debates about the legitimacy of supranational courts and the international rule of law are the modern counterparts to the old question about the effectiveness of international law. The current discussions result from a deep discomfort about the deformalisation of international law-making that is characterised by informal norms, informal actors and informal norm-making processes. ${ }^{4}$ Ultimately, these discussions still express a quest for a legitimate alternative to 'state will' as a ground for international legal validity and legitimacy.

This deformalisation results from normative activities of a multitude of non-state actors, including regional and international organisations and their organs, expert bodies, non-governmental organisations, private initiatives, or combinations of these. The diversification of actors and their normative activities beyond the sovereign state has opened the door for multiple conceptualisations of the international order that try to make sense of this normative diversity. These conceptualisations are as diverse as their subject and include constitutional approaches, governance studies and global administrative law, regime theory, constructivist and sociological approaches that rely, for example, on epistemic communities, norm entrepreneurs, discourse analysis and socialisation effects in order to explain the nature and relations of normative processes.

The place of regional and international courts and tribunals in this normative kaleidoscope is special because judicial authority is an institutionalised authority of binding decision-making. Judicial authority entails through its institutionalisation and professional endowment a 'legitimacy credit'. The establishment of courts implies a bestowal and acceptance of binding authority whose legitimacy is initially instituted and later questioned and defended. It is in this tension between the

2000); A Stone Sweet, The Judicial Construction of Europe (Oxford University Press, Oxford, 2004); OK Fauchald and A Nollkaemper (eds), The Practice of International and National Courts and the (De-)Fragmentation of International Law (Hart Publishing, Oxford and Portland, OR, 2012); RG Teitel, Transitional Justice (Oxford University Press, Oxford, 2000); A-M Slaughter, A New World Order (Princeton University Press, Princeton, NJ and Oxford, 2004); E Benvenisti and GW Downs, 'Court Cooperation, Executive Accountability, and Global Governance' (2009) 41 New York University Journal of International Law and Politics 931; A Nollkaemper, National Courts and the International Rule of Law (Oxford University Press, Oxford, 2011).

${ }^{4} \mathrm{~J}$ d'Aspremont, Formalism and the Sources of International Law: A Theory of the Ascertainment of Legal Rules (Oxford University Press, Oxford, 2011). 
institutionalisation and the social inter-actional process where the legal and socio-political approaches to judicial legitimacy and the (international) rule of law meet. ${ }^{5}$

This special issue lies at this sweet spot, and we move from the domestic to the supranational. Professor Jeremy Waldron and Professor Brian Tamanaha open the discussion with the well-known debate on the rule of law and judicial review. Both answer the question what the rule of law requires and how a 'trade-off' between judicial review and democracy should play out differently. Jeremy Waldron cautions against the possibility that judges become Hobbesian sovereigns and follow their own political programme. In his comment, Brian Tamanaha stresses that the alleged trade-off is misconceived because the rule of law can be instantiated in different ways which makes it difficult to pick discrete elements that need to be traded against each other. In addition, he points out that democracy has its own flaws and so does the rule of law which is not an absolute political value but remains after all always a relative achievement.

Professors Waldron and Tamanaha advocate both a 'thin' understanding of the rule of law that does not require any particular substantial content. This is contrary to what Professor Andreas Follesdal suggests in his discussion of the international rule of law with a particular focus on the European Court of Human Rights. He asks which interests of the individual does the rule of law protect and promote at the domestic level and how can these interests be extended to the supranational level. He focuses principally on non-domination and predictability and discusses how the doctrine of the margin of appreciation and the election procedures to the bar can foster or weaken the rule of law. Professor Gianluigi Palombella emphasises in his comment that beyond any substantive elements it is the institutional context that matters most for the rule of law, in particular the plurality of law-making sources beyond a single sovereign.

The importance of 'another law' that the sovereign cannot overwrite at will, that Gianluigi Palombella stresses, points to a particular paradigmatic expression of the rule of law and legitimate authority, namely that of a constitutionalisation beyond the state. ${ }^{6}$ Professor Geir Ulfstein and Professor Wojciech Sadurski discuss the prospects and nature of a transnational constitutionalisation of the Strasbourg court. Neither Geir Ulfstein nor

5 J Brunée and SJ Toope, Legitimacy and Legality in International Law: An Interactional Account (Cambridge University Press, Cambridge, 2010).

${ }^{6}$ M Kumm, 'The Legitimacy of International Law: A Constitutionalist Framework of Analysis' (2004) 15 European Journal of International Law 907; see also J Klabbers, A Peters and G Ulfstein (eds), The Constitutionalization of International Law (Oxford University Press, Oxford, 2009). 
Wojciech Sadurski speak of an actual constitution but rather of a constitutional pluralism. Professor Ulfstein identifies constitutional functions that the European Court of Human Rights fulfils and suggests a co-operative realisation of these functions where the Strasbourg court and national courts engage in a common legal enterprise. Professor Sadurski adds to this vision two further instances of constitutionalisation: first, the pilot judgments through which the Court addresses systemic deficits in national legal systems and thus ensures a 'minimal constitutional harmony' throughout the Council of Europe system. Another addition that Wojciech Sadurski makes to the constitutional mix is the increasing role of the Strasbourg court in the implementation of its own judgments which allows it to play a more integrated role in national legal systems without the political intermediation of the Committee of Ministers. Ultimately, he suggests to locate the legitimacy for these constitutional ambitions in the argumentative resources of the court and in public reason rather than abstract democratic theory.

The legitimacy question leads to two cautionary contributions that close the special issue. Professor Friedrich Kratochwil and I discuss the legitimising potential of judicial dialogue and the pitfalls of judicial governance. I caution against an idealisation of judicial dialogue as a means to foster commonalities between courts and to legitimise judicial governance. I point to numerous systemic obstacles that taint the legitimising quality of judicial dialogue when its purpose and meaning is taken beyond cross-fertilisation and comparative reasoning. The critical potential of judicial dialogues lies less in the formation of common opinions than in the plurality of voices and opinions that both represent and resonate in local publics and counterpublics. Friedrich Kratochwil is more cautious about the role of courts in public discourses. He points us to the problem of confirmatory research that supports broad conceptions of judicial governance through dialogue or networks and criticises the 'mainstreaming' (or paternalistic) tinge that taints the talk about 'learning', 'cross-fertilisation' and 'dialogue'. Instead he emphasises that this form of judicial paternalism cannot dispense with politics. What we actually see is often a clash between different forms of functional legitimisation through different systems, for there exist different sources of legitimacy which stand in tension with each other. Similar to Gianluigi Palombella, also Friedrich Kratochwil points out that in the republican institutional set-up there is not a single supreme authority but a process among different institutions that compete for a practicable solution.

All authors in this special issue share the conviction that there is not a single conception of the rule of law, legitimacy and judicial authority. Call it thick or thin; hard, soft or liquid; strong or weak; input, output 
or throughput; instant or continual; origin or exercise; formal, procedural or substantial - there is disagreement not only about the substantial content of the rule of law and legitimate authority but also about the normative basis, meanings and proper uses. ${ }^{7}$ The substantial content and the institutional expression of these concepts can and must vary. Yet despite this disagreement, the rule of law and the legitimate exercise of authority are cherished values of political communities. Ultimately, we need to ask ourselves whether and why we really need to decide about the 'correct' or 'proper' or 'best' conception when we discuss the rule of law, legitimacy and judicial authority. This leads us to the role of interpretive and contested concepts in political and legal discourses which I want to address in the following sections. The conflicting conceptions of the rule of law and legitimacy that follow from the interpretive and essentially contested nature of these concepts both enable and condition that there is not a single and dominating source of authority.

I mentioned at the beginning that judicial authority, the rule of law and legitimacy are not only topics for the Anglo-American academic world. I should also mention that they are neither topics only for an exclusively occidental or male world. ${ }^{8}$ Unfortunately, this special issue did not succeed in reflecting other important voices. Two invited contributions which would have added some diversity did not materialise. The hope persists that the discussions here will inspire further debates beyond the social confines of discipline, gender and geography.

\section{Contested concepts and contested authorities}

Against the background outlined above, I would like to make three claims in this Introduction about the conceptual triangle of the rule of law, judicial authority and legitimacy.

\section{Contested and interpretive conceptions}

The first claim is that all three are essentially contested and interpretive concepts. Walter B. Gallie famously identified essentially contested concepts as: 'concepts the proper use of which inevitably involves endless disputes

7 J Waldron, 'Is the Rule of Law an Essentially Contested Concept (in Florida)?' (2002) 21 Law and Philosophy 137; BZ Tamanaha, 'A Concise Guide to the Rule of Law' in G Palombella and N Walker (eds), Relocating the Rule of Law (Hart Publishing, Oxford and Portland, OR, 2009) 3.

${ }^{8}$ For an important contribution in this regard that provides varied perspectives, see P Costa and D Zolo (eds), The Rule of Law: History, Theory and Criticism (Springer, Dordrecht, 2007). 
about their proper uses on the part of their users'. ${ }^{9}$ Concepts of this kind and their differing functions and uses are sustained by endless disputes which, 'although not resolvable by argument of any kind, are nevertheless sustained by perfectly respectable arguments and evidence'. ${ }^{10}$

Gallie defined seven conditions for concepts to qualify as essentially contested. Such a concept must be appraisive in the sense that it expresses a valued achievement; it must be internally complex, for it consists of different aspects and features that can be valued differently; it allows for rival descriptions of the achievement and of the value of its constituent features; it is open to change over time; it requires an appreciation that one's own use is contested and that other uses exist (the concept is used both aggressively and defensively); it derives from an original exemplar whose authority is acknowledged by all contestant users; and it sustains the claim that only through continuous contestation can the original exemplar's achievement be sustained or developed in optimum fashion. ${ }^{11}$

Referring also to Gallie's work, Ronald Dworkin regarded law as an interpretive concept. ${ }^{12} \mathrm{He}$ understood law as a social practice that is interpreted by members of an interpretive community who, as participants in the practice, may share basic assumptions about the practice but engage in constructive and partisan interpretations to propose and justify value for the practice and make it the best possible example (conception) of the genre or enterprise to which it is taken to belong (concept). ${ }^{13}$ For Dworkin, interpretive concepts are about contested values: 'their descriptive sense is contested, and the contest turns on which assignment of a descriptive sense best captures or realises that value. Descriptive meaning cannot be peeled off from evaluative force because the former depends on the latter in that way.' 14

9 WB Gallie, 'Essentially Contested Concepts' in WB Gallie (ed), Philosophy and the Historical Understanding (Chatto \& Windus, London, 1964) 157.

${ }^{10}$ Ibid.

11 Ibid 161-8; I will not go into detail about the applicability of Gallie's seven conditions to the concepts under consideration here but have no doubt that they apply to the rule of law, legitimacy and (judicial) authority; see also Waldron ( $\mathrm{n} 7$ ); it should be mentioned, however, that Gallie indicated some doubt whether 'law' and 'authority' would qualify as essentially contested concepts, for they seemed to him 'to be tied to more specific aims and claims, as well as admitting of more easily agreed tests', see Gallie (n 9) 190.

12 R Dworkin, Taking Rights Seriously (Duckworth, London, 1977) 103 referring to Gallie in the context of a concept that admits different conceptions.

13 R Dworkin, Law's Empire (Fontana Press, London, 1986) 52-3, especially Chapter 2 and 3; R Dworkin, 'Hart's Postscript and the Character of Political Philosophy (2004) 24 Oxford Journal of Legal Studies 1; R Dworkin, Justice in Robes (Belknap Press, Cambridge, MA, 2006) 10-12.

14 Dworkin, 'Hart's Postscript' (n 13) 9. 
The theories of the two scholars share some striking similarities. Both distinguish between a concept, different conceptions of this concept and different functions of concepts (e.g. criterial, natural kind and interpretive). ${ }^{15}$ Both acknowledge that there usually is - to different degrees - a general appreciation within a community of a practice or a concept. There exists a pre-interpretive sense of the standing features of a practice, but not a single common definition. ${ }^{16}$

Distinct from the concept (or original exemplar) are the conceptions about this concept. Conceptions are interpretive variations that assign different and at times competing purposes and value to a concept. Each interpretive variation tries to develop the best possible version of the concept. ${ }^{17}$ Conception-making is, therefore, a normative, engaged, constructive, morally and ethically evaluative, in short, an appraisive and interpretive process because it is not a mere neutral description, but proposes and justifies the arguably most valuable version of the concept.

This Introduction is not the place to discuss the disputes surrounding Gallie's and Dworkin's accounts and the many debates surrounding conceptual analysis, indeterminacy and semantics. For our purposes, what interests us most is what the qualification of a concept as essentially contested or interpretive means.

To begin with, this qualification is an important reminder that we talk about social institutions that are historically and socially contingent and relate to learned practices. The rule of law, legitimacy and judicial authority are not natural phenomena that can be isolated, described and analysed in terms of universal (or universalisable) criteria. This might seem trivial but is all too often neglected. More importantly, the existence of historically, geographically and theoretically varying and at times contradictory conceptions points us to the importance of contestation. Both Gallie and Dworkin emphasise the multitude of uses

15 Dworkin, Justice in Robes (n 13) 223-6; R Dworkin, Justice for Hedgehogs (Belknap Press, Cambridge, MA, 2013) 158-60 distinguishes further between different types of concepts (doctrinal, sociological, taxonomic and aspirational).

16 Gallie (n 9) 168 (his sixth condition); Dworkin, Taking Rights Seriously (n 12) 134-5; Dworkin, Law's Empire (n 13) 66-7; 70-1 and 92-3; Dworkin, 'Hart's Postscript' (n 13) 7-8; in Dworkin, Justice in Robes (n 13) 224, he states that sharing an interpretive concept by participating in a social practice 'does not require any underlying agreement or convergence on either criteria or instances'; in Dworkin, Justice for Hedgehogs (n 15) 161, he adds that '[s]haring an interpretive concept does depend, as sharing criterial and natural-kind concepts depends, on agreement. But the kind of agreement that is required in the case of an interpretive concept is very different: it is not agreement on a decision procedure as a decisive test for instances. On the contrary, sharing an interpretive concept is consistent with very great and entirely intractable differences of opinion about instances.'

17 Gallie (n 9) 168 (his seventh condition); Dworkin, Law's Empire (n 13) 52-3 and 74. 
and related disagreement. ${ }^{18}$ As also Professors Waldron and Tamanaha emphasise, there is genuine and principled disagreement about the functions and values of these concepts and about what constitutes the 'best' or 'right' conception of them. ${ }^{19}$

Appealing to and using an essentially contested and interpretive concept means challenging others to develop and apply their own conception which may or may not correspond to my own conception. Proposing a conception is defining a meaning that others may challenge. ${ }^{20}$ It means that 'a useful analysis of an interpretive concept ... cannot be neutral. It must join issue in the controversies it hopes to illuminate. ${ }^{21}$ Recognising the essentially contested and interpretive nature means, therefore, not merely acknowledging that other conceptions exist, but that these other conceptions have 'permanent potential critical value to one's own use or interpretation of the concept in question'. ${ }^{22}$

In addition, the notions of essentially contested and interpretive concepts point us to questions about the semantic borders of these concepts, how these borders are drawn, by whom, for what purposes and with what effects. These concepts are actor- and context-depended, historically contingent and are not normatively universal and neutral. This is an almost classic insight from constructivism about social institutions. As Friedrich Kratochwil has reminded us, the meaning of a concept like legitimacy depends on the semantic field it is used in. Hence any conceptual analysis of the rule of law, legitimacy and authority has to relate these concepts

18 Gallie (n 9) 157-8 and 187-90; Dworkin, Taking Rights Seriously (n 12) 135; Dworkin, Law's Empire (n 13) 83-6.

19 Gallie (n 9) 160; Dworkin, Law's Empire (n 13) 71; in Dworkin, Justice for Hedgehogs (n 15) 164 he writes that interpretive concepts help us 'to understand as well as describe how and why people disagree and argue. We want to see whether the disagreement is genuine. But we also need to recognise interpretive concepts to guide our own arguments'; J Raz, 'The Law's Own Virtue' (2019) 39 Oxford Journal of Legal Studies 1, 1 writes: 'There is no agreement what [the rule of law] is: this lack of agreement is common to important normative institutions and principles ... The lack of agreement is often a source of strength - people unite in supporting such institutions and principles in spite of diverse views about their nature'; see also in this issue J Waldron, 'The Rule of Law and the Role of Courts' (2021) 10 Global Constitutionalism 91-105; and BZ Tamanaha, 'Always Imperfectly Achieved Rule of Law: Comments on Jeremy Waldron' (2021) 10 Global Constitutionalism 106-117.

20 Gallie (n 9) 161 (his fifth condition); Dworkin, Taking Rights Seriously (n 12) 135.

21 Dworkin, Justice in Robes (n 13) 225.

22 Gallie (n 9) 188; Stephen Guest, Ronald Dworkin (Edinburgh University Press, Edinburgh, 1992) 35-6 suggests that a justification for the existence of essentially contestable [sic!] concepts is that we have responsibility to 'construct' answers to interpretive questions instead of leaving them unanswered or to someone else to venture an answer; see also ME Criley, Contested Concepts and Competing Conceptions (University of Pittsburgh, Pittsburgh, PA, 2007) 63-83. 
also to each other and to other concepts in the semantic field such as accountability, justification and democracy but also to trust, integrity and legality. ${ }^{23}$ It also requires us to think how they took on the meaning they have now (that is how and for what purposes we use them), who were the influential actors in their development and against which other conceptions did they prevail.

Thus, as Gallie originally stated, a deeper understanding of the essentially contested and interpretive nature of concepts 'requires some appreciation of their history - of how they have come to be used in the ways they are'. ${ }^{24}$ This historical view implies an understanding of the genealogy of the different conceptions over time and of the ill-foundedness of any claim to exclusive validity of a particular conception. Conceptions are intelligible only as contributions to a seemingly endless, although at its best a creative, conflict'. ${ }^{25}$ It is the very concept-conception distinction that provides the space to test and contest the rationality and justification of arguments and ultimately (hopefully) raises 'the level of quality of arguments in the disputes of the contestant parties'. ${ }^{26}$ Professor Waldron refers to the importance of 'housing' in the context of institutions, ${ }^{27}$ so we may say that the valued concept provides the housing for our conflicts that we express through differing conceptions. The historical perspective allows to connect these struggles, structure the disputes and relate them to each other and to the common concept.

\section{Contested authorities}

My second point is then a proposition about the actual use of conceptions of essentially contested and interpretive concepts as arguments. The approximation to the 'best', 'optimal' or 'correct' use of these concepts through the proposition of particular conceptions is interest- and purposedriven. Also for this reason contestation is so fundamental, for only through continuous contestation can we identify and question these underlying interests and objectives. The supranational conceptions of the rule of law

23 F Kratochwil, 'On Legitimacy' (2006) 20 International Relations 302, 307; Dworkin, 'Hart's Postscript' (n 13) 17 and 25-6; Dworkin, Justice for Hedgehogs (n 15) 164; on the importance of context, see also J Raz, 'Two Views of the Nature of the Theory of Law: A Partial Comparison' (1998) 4 Legal Theory 249, 255-6.

24 Gallie (n 9) 158, 168 and 189.

25 Gallie (n 9) 177 and 184, where he remarks that the historical perspective permits 'to explain or show the rationality of a given individual's continued use, or in the more dramatic case of conversion his change of use, of the concept in question' (emphasis in the original).

26 Gallie (n 9) 188.

27 J Waldron, 'Political Political Theory' in J Waldron, Political Political Theory (Harvard University Press, Harvard, MA, 2016) 1-22. 
and legitimacy, for example, point us to processes of expansion and diversification of authority which all of the contributors in this issue address. With hindsight, the emergence of every new supranational actor and their intention to cement and enlarge their normative relevance has been met with questions about their legitimacy and compliance with the rule of law. In fact, the different 'isations' discussed in international scholarship over recent years - e.g. institutionalisation, 'communitisation', humanisation, constitutionalisation, fragment(is)ation, deformalisation, judicialisation or expertisation - all express a preoccupation with normative developments driven forward by particular actors. ${ }^{28}$

Thus questions about the legitimacy of international organisations began to surface especially when these started to interpret and act beyond their functional settings. ${ }^{29}$ Commentators questioned the legitimacy of the UN Security Council when it began to 'legislate' or when it failed to act decisively to crisis. ${ }^{30}$ The legitimacy of UN treaty bodies became an issue when their claims to increased 'semantic authority' became more demanding and their interpretations more telos-oriented. ${ }^{31}$ The legitimacy of international criminal tribunals was questioned in relation to novel constructions of customary law. ${ }^{32}$ The supranational rule of law is mainly discussed in the context of new normative actors in the post-national constellation. ${ }^{33}$

28 See also in this issue G Ulfstein, 'Transnational Constitutional Aspects of the European Court of Human Rights'(2021)10 Global Constitutionalism 151-174; and W Sadurski, 'Quasi-Constitutional Court of Human Rights for Europe? Comments on Geir Ulfstein' (2021) 10 Global Constitutionalism 175-185.

29 A Buchanan and RO Keohane, 'The Legitimacy of Global Governance Institutions' (2006) 20 Ethics and International Affairs 405; T Christiano, 'The Legitimacy of International Institutions' in A Marmor (ed), The Routledge Companion to Philosophy of Law (Routledge, London, 2012) 381.

${ }^{30}$ I Hurd, After Anarchy: Legitimacy and Power in the United Nations Security Council (Princeton University Press, Princeton, NJ, 2007); C Gray, 'A Crisis of Legitimacy for the UN Collective Security System?’ (2007) 56 The International and Comparative Law Quarterly 157.

31 See the collection by H Keller and G Ulfstein (eds), UN Human Rights Treaty Bodies: Law and Legitimacy (Cambridge University Press, Cambridge, 2012).

32 See B Schlütter, Developments in Customary International Law: Theory and the Practice of the International Court of Justice and the International ad hoc Criminal Tribunals for Rwanda and Yugoslavia (Brill, Leiden, 2010).

33 J Waldron, 'The Rule of International Law' (2006) 30 Harvard Journal of Law \& Public Policy 15; S Chesterman, 'An International Rule of Law?' (2008) 56 American Journal of Comparative Law 331; I Hurd, 'The International Rule of Law and the Domestic Analogy' (2015) 4 Global Constitutionalism 365; R McCorquodale, 'Defining the International Rule of Law: Defying Gravity?' (2016) 65 International and Comparative Law Quarterly 277; H Krieger and G Nolte, 'The International Rule of Law - Rise or Decline? Points of Departure' (2016) KFG Working Paper Series, No. 1 <https://papers.ssrn.com/sol3/papers.cfm?abstract_id=2866940>; M Kumm, 'Global Constitutionalism and the Rule of Law' in AF Lang Jr. and A Wiener (eds), Handbook on Global Constitutionalism (Edward Elgar Publishing, Cheltenham, 2017) 197. 
Hence also the legitimacy of courts and tribunals has attracted attention when they went beyond the adjudication of cases and became (or were made) central to the proactive development of legal regimes. ${ }^{34}$

This contestation of authority in the name of legitimacy is about contested competencies. Arguments about the rule of law and legitimacy usually do not arise as a matter of principle or abstract normative concern, but as a means of questioning or securing the authority of a particular actor or institution in relation to other actors and institutions. Both justification and contestation of competencies rely on contingent conceptions of the rule of law, legitimacy and authority.

These ongoing discussions about the deformalisation of normative authority and its legitimation form part of a 'sociological (re)turn' - or practice (re)turn - in international law and political theory. Scholars 'acknowledge' the new forms of claiming and of exercising normative authority and new explanatory models follow. ${ }^{35}$ The new authoritative practices require, so the argument goes, an adaptation of our concepts to the new circumstances and challenges. Hence new conceptions follow. Our domestic concepts - not any less contested - are transposed or extrapolated to new spheres, and new theories about the globalised rule of law, legitimacy, justice, governance, etc follow. The ongoing debates are thus as much about de-formalisation as they are about the formalisation of new practices.

\section{Transposition and transformation}

My third point relates to this process of transposing concepts from the domestic to the supranational levels which several contributions in this issue address. ${ }^{36}$ We usually do not pause to ask whether the international legal order really needs to correspond to the domestic rule of law ideal and democratic legitimacy standards. Does it really make sense to analyse the process of (international) adjudication through the lens of democratic

34 Alter (n 2); A von Bogdandy and I Venzke, In Whose Name?: A Public Law Theory of International Adjudication (Oxford University Press, Oxford, 2014); see the contributions in N Grossman, HG Cohen, A Follesdal and G Ulfstein (eds), Legitimacy and International Courts (Cambridge University Press, Cambridge, 2018).

35 See the collection of essays in A Geis, F Nullmeier and C Daase (eds), Der Aufstieg der Legitimitätspolitik: Rechtfertigung und Kritik politisch-ökonomischer Ordnungen (Nomos, Baden-Baden, 2012).

36 See in this issue A Follesdal, 'International Human Rights Courts and the (International) Rule of Law: Part of the Solution, Part of the Problem, or Both?' (2021) 10 Global Constitutionalism 118-138; and G Palombella, 'Non-Arbitrariness, Rule of Law and the "Margin of Appreciation": Comments on Andreas Follesdal' (2021) 10 Global Constitutionalism 139-150; Ulfstein (n 28); Sadurski (n 28); see also the contributions in G Palombella and $\mathrm{N}$ Walker (n 7). 
theory - and usually in terms of particular ideals picked from the latter? Since we transpose essentially contested and interpretive concepts, which conceptions do we choose and why? Analysing adjudication in terms of legitimacy implies already a move from a task (deciding a dispute in terms of law) to a practice of governance (the exercise of public authority). All too often we move too quickly to a 'universalisable' conception without acknowledging even local differences. As Jeremy Waldron and Brian Tamanaha emphasise, the rule of law entails trade-offs that are inherently local and political, and these trade-offs differ not only between communities but also change within one polity over time. A question of crucial importance is then which conception is really transposed and how does the transposition influence the meaning of the concept? What gets lost and which layers of meaning are added? Which new constituencies become empowered and which of the older ones become supplanted? Transposing concepts means making new conceptions - both supranationally and domestically. It also means legitimising new authorities at the cost of others - both institutionally and individually.

Thus one would wish that the discussions in this special issue also caution against discourses about the legitimacy of global (judicial) governance and the international rule of law that ultimately are more about legitimation than about legitimacy and more about new ways of ruling than the rule of law. In many writings about authority in 'post-national constellations' (often far from Habermas' original concern), the fashionable identification of multiplicities and pluralities leaves one often with little else than that some form of authority can be found anywhere. ${ }^{37}$ At times one wonders if the next step after soft power, soft law and soft authority, is not smart law or smart authority and not an even more softened liquid state, but gaseous authority - that is hot air.

Ultimately, the very concept or the original exemplar that underlies the different conceptions might become devalued. This is a danger of essentially contested and interpretive concepts that Walter Gallie and Ronald Dworkin did not really address. None of the contributions in this issue goes that far. To the contrary, the authors often stress the relevance of formal settings, institutions and constitutional values. It is thus worth remembering that with all the differentiations and conceptualisations about 'new' forms of public authorities, we are actually still concerned with the lawful exercise of authority. Beyond the allegedly 'descriptive' attitude that Dworkin so deeply criticised, we

37 Other frequently used terms are informalities, porosities, dynamisms, disaggregations, reflexivities, complexities, broadenings, fluidities, networks, structures, practices, spaces and so on. 
need to identify the underlying interpretive interests and functional uses of the conceptions of the rule of law, legitimacy and judicial authority if we want to understand the purposes and meanings of the conceptions that we develop and use. ${ }^{38}$

\section{Conclusion}

One conclusion of this short discussion is that it would amount to a naïve fallacy to assume that with a sufficiently sophisticated normative theory of legitimacy, of the rule of law, of constitutionalism or normative pluralism, problems of supranational legitimacy and the rule of law could be answered 'correctly'. This would also be a profound misunderstanding of the role of essentially contested and interpretive concepts in political and legal discourses. In Gallie's exposition, the contested nature of concepts is nothing to be 'solved', but it is essential to their purpose. ${ }^{39}$ The continuous contestation of different conceptions, functions, meanings and uses does not change that we value the concept or the ideal it represents. Only through this ongoing contestation and continuous competition with rival conceptions do these concepts fulfil their purpose. As Gallie wrote:

It is in this conception of a possible optimum (never finally achieved and approachable by a variety of routes and through a variety of results as between different competing claims) that the unity of an essentially contested concept may be said to reside (or at least to be made manifest) and that, consequently, its continued use can be justified. ${ }^{40}$

Professor Waldron made an apt qualification to the understanding of the rule of law as an essentially contested concept, namely that 'the contestation is not so much about ways of characterising an achievement that we already have, but rather about ways of answering a challenge - how to make law rule,

38 See on this point in this issue also K Traisbach, 'A Transnational Judicial Public Sphere as an Idea and Ideology: Critical Reflections on Judicial Dialogue and Its Legitimizing Potential' (2021)10 Global Constitutionalism 186-207; and F Kratochwil, 'Law as an Argumentative Practice: On the Pitfalls of Confirmatory Research, False Necessities, and (Kantian) StupidityComments on Knut Traisbach' (2021) 10 Global Constitutionalism 208-220.

39 Gallie (n 9) 167.

40 Ibid; see also Waldron (n 7) 151-2: “Essential contestability”, then, is about a way in which certain ideals are present to us. ... But in the case of essentially contested concepts, they are present to us only in the form of contestation about what the ideal really is. ... [T]he contestation between rival conceptions deepens and enriches all sides' understanding of the area of value that the contested concept marks out.' 
rather than men - which many are convinced cannot be answered'. ${ }^{41}$ More than referring back to a valued achievement (or an original exemplar), he submits, there is also contestation about the value perception as such, including the reasons for valuing it. Ultimately, he writes, 'a society ruled by laws, not men, is bound to be a society in which there is constant debate about what the Rule of Law means' ${ }^{42}$

I agree with this qualification and believe this tells us also something important about Professor Waldron's own views on judicial review of legislation. The trade-offs between different conceptions of ideals and values, such as between judicial review and democracy (or between majoritarian legislation and democracy), are not a danger to the rule of law but its essential expression. The rule of women and men in courts must be questioned, but also in parliament, in government and in other institutions - local, national, regional and international. Challenges in the name of the rule of law are the best expression of the rule of law. ${ }^{43}$

The crux of essentially contested and interpretive concepts is the challenge they pose to a political and legal community, but the challenge is not to find permanent agreement on any ideal or a trade-off between ideals. It is about how to accommodate constant debate. We may even say, therefore, that Dworkin's Judge Hercules would be difficult to reconcile with the rule of law, democratic principles and legitimate authority. This has important implications for the role of normative and institutional political theory. It also tells us something about legitimacy. Legitimate authority does not only depend on the degree an authoritative actor lives up to values like fairness, justice, human dignity, accountability or any other instrumental value or procedural guarantee. It also depends on how an authoritative actor permits, accommodates and responds to contestation.

Another conclusion follows from the discussions in this issue: essentially contested and interpretive concepts depend on multiple actors. An actor alone cannot produce or guarantee its own legitimacy or the rule of law by itself. This is not a paradox of liberalism as it is often claimed for the

41 Waldron (n 7) 157; he adds at 159 that '[t]here is contestation about the content and requirements of the Rule of Law ideal, and there is contestation about its point' (emphasis in the original); about the essential role of contestation for law and politics, see A Wiener, A Theory of Contestation (Springer, Heidelberg, 2014) and A Wiener, Contestation and Constitution of Norms in Global International Relations (Cambridge University Press, Cambridge, 2018).

42 Waldron (n 7) 164; see also J Waldron, 'The Concept and the Rule of Law' (2008) 43 Georgia Law Review 1, 52.

${ }^{43} \mathrm{~N}$ MacCormick, Rhetoric and the Rule of Law (Oxford University Press, Oxford, 2005) 27. 
famous Böckenförde Dilemma, but an inherent characteristic of an open community. Courts, like all authoritative actors within a rule of law polity, have limited legitimacy resources of their own. They cannot fully control their legitimatory openness towards other actors. Thus any reduction of focus about legitimacy and the rule of law upon one branch of government, one group of actors or one level (local, domestic, regional or international) misunderstands the importance of the interoperation (not collaboration) of multiple actors for the rule of law and legitimacy. The biggest challenge lies then in the in-betweens: ${ }^{44}$ the relations between conceptions, between actors, between institutions and between levels. The different contributions in this issue provide ample opportunity to test these connecting spaces.

44 J Waldron, 'The Constitutional Politics of Hannah Arendt' in Waldron (n 27) 290, 294. 